\title{
Protein Encapsulation into PLGA Nanoparticles by a Novel Phase Separation Method Using Non-Toxic Solvents
}

\author{
Amin Swed ${ }^{1}$, Thomas Cordonnier ${ }^{1}$, Fabrice Fleury ${ }^{2}$ and Frank Boury ${ }^{1 *}$
}

${ }^{1}$ LUNAM University, UMR S-1066 INSERM, Micro-Nanomédecines Biomimétiques, 49933 Angers, France

${ }^{2}$ LUNAM University, Mechanism and Regulation of DNA repair-IMPACT, UFIP UMR CNRS 6286, 44322 Nantes, France

\begin{abstract}
Nanoparticles of biocompatible and biodegradable polymers such as poly(lactic-co-glycolic acid) (PLGA) are widely used as drug delivery systems for the administration of biomolecules like proteins. The purpose of this work is to validate a novel formulation method by a phase separation phenomenon using the non-toxic solvent glycofurol (GF) in order to encapsulate proteins into PLGA nanoparticles. Nanoprecipitates of a model protein (lysozyme) and a therapeutic protein (TGF- $\beta 1$ ) were formed to ensure their stability upon subsequent encapsulation into PLGA nanoparticles. Good encapsulation efficiency was obtained with preservation of the structure integrity and protein bioactivity after encapsulation. PLGA nanoparticles were then characterized in terms of size, zeta potential and morphology. Moreover, residual solvent was quantified and in vitro release study of the encapsulated proteins was performed to demonstrate the efficacy of our encapsulation method in drug sustained release. Finally, cytocompatibility study of nanoparticles was performed. Thus, we developed an effective method based on the preliminary step of protein precipitation for the formulation of PLGA nanoparticles as protein carriers for biomedical applications.
\end{abstract}

Keywords: Glycofurol (GF); Phase separation; Protein encapsulation; poly(lactic-co-glycolic acid) (PLGA); Non-toxic solvent; Nanoparticles (NPs); Lysozyme; Transforming growth factor betal (TGF- $\beta 1$ ); Sustained release

\section{Introduction}

To date, protein encapsulation is a very promising area of research since many proteins are now available thanks to the recent advances in biotechnology. However, their use for therapeutic purpose remains a challenge in the field of nano and microencapsulation due to physical and chemical instability, proteolysis and short half-life. Protein encapsulation into polymeric systems such as PLGA particles has proven to be a versatile approach to protect these biomolecules, to allow their sustained delivery and to improve their therapeutic efficacy $[1,2]$. Therefore, various methods have been used for the formulation of PLGA particles loading proteins such as nanoprecipitation $[3,4]$, spraydrying and spray-freeze-drying [5-7], phase separation (coacervation) $[8,9]$, water/oil/water $(\mathrm{w} / \mathrm{o} / \mathrm{w})[10,11]$, solid/oil/water $(\mathrm{s} / \mathrm{o} / \mathrm{w})[12,13]$ and other derivative methods $[14,15]$. The main drawback of these techniques is the use of volatile organic solvents which have a potential toxicity and so are considered harmful to human health and the environment. For example, halogenated solvents such as methylene chloride and chloroform are commonly used to dissolve the PLGA in the encapsulation process $[16,17]$. As alternative, less-toxic solvents were used such as ethyl acetate [13,18], ethyl formate [19], methyl ethyl ketone [20] and acetone [21]. In this sense, non-volatile water-miscible solvents, which are safer than the volatile ones, were used like dimethyl sulfoxide and N-methyl pyrolidone [4]. Otherwise, supercritical fluids, especially $\mathrm{CO}_{2}$, were proposed to completely substitute organic solvents or to minimize their use $[22,23]$.

Hence, preparation of PLGA particles using non-toxic solvents would be of great interest to reduce the toxicity and to preserve protein integrity. Among these solvents, glycofurol (GF) and isosorbide dimethyl ether (DMI) appear to be the two safest injectable solvents, which have considerably low toxicity profiles confirmed by many scientific studies [24-29]. For this reason, they were used in many drug products for different therapeutic purposes [30-37] and for the formulation of PLGA particles as polymer solvents [38-42].

In our previous study, we have introduced the formulation of
PLGA nanoparticles by a novel phase separation method called nanoprecipitation using glycofurol as polymer solvent [38]. In the present work, in addition to the encapsulation of lysozyme as a model protein, TGF- $\beta 1$ was chosen to be loaded into these nanoparticles due to its important role in cell proliferation, differentiation and extracellular matrix metabolism [43]. Therefore, controlled release of TGF- $\beta 1$ might be of great interest in cartilage tissue engineering [44,45]. Proteins were firstly precipitated using GF or a mixture of GF and DMI to ensure their stability and were then encapsulated into the nanoparticles. Physicochemical properties of these nanoparticles were investigated and solvent residual content was quantified. Moreover, different techniques were performed to confirm the protein integrity and bioactivity upon the encapsulation. Besides, in vitro release of the proteins from PLGA nanoparticles was presented to ensure the utility of these carriers in drug sustained release. Furthermore, cytotoxicity of nanoparticles was assessed as preliminary evaluation of the cytocompatibility of these systems which will be used in cartilage tissue engineering application. This work is involved in a global project which aims to conceive novel biomaterials composed of implantable synthetic extracellular matrices combined with TGF- $\beta 1$-loaded particles for cartilage regeneration. However, the application of obtained polymeric systems might be extended to any domain requiring protein encapsulation.

\section{Materials and Methods}

\section{Materials}

Lysozyme (14 kDa) from chicken egg-white, Micrococcus

*Corresponding author: Frank Boury, LUNAM University, UMR S-1066 INSERM, MicroNanomédecines Biomimétiques, 49933 Angers, France, Tel: 33-2-44-688528; Fax: 33-244-688546; E-mail: frank.boury@univ-angers.fr

Received September 24, 2014; Accepted November 06, 2014; Published November 15, 2014

Citation: Swed A, Cordonnier T, Fleury F, Boury F (2014) Protein Encapsulation into PLGA Nanoparticles by a Novel Phase Separation Method Using Non-Toxic Solvents. J Nanomed Nanotechnol 5: 241. doi: 10.4172/2157-7439.1000241

Copyright: (c) 2014 Swed A, et al. This is an open-access article distributed under the terms of the Creative Commons Attribution License, which permits unrestricted use, distribution, and reproduction in any medium, provided the original author and source are credited. 
lysodeikticus, glycofurol (tetraglycol or $\alpha$-[(tetrahydro-2-furanyl) methyl]- $\omega$-hydroxy-poly(oxy-1,2-ethanediyl, isosorbide dimethyl ether (1,4:3,6-Dianhydro-2,5-di-O-methyl-D-glucitol), dimethyl sulfoxide (DMSO), NaCl, Lutrol ${ }^{\circledR} \mathrm{F} 68$ (poloxamer 188) and bovine serum albumin (BSA) were obtained from Sigma-Aldrich (Saint Quentin Fallavier, France). Ethanol was obtained from Fischer Scientific. Human TGF- $\beta 1$ was purchased from Peprotech (Paris, France). TGF- $\beta 1$ ELISA Kit was obtained from R\&D Systems (Lille, France). Micro-BCA protein assay reagent kit was purchased from Pierce (Bezons, France). Uncapped 75/25 PLGA provided by Phusis (Saint-Ismier, France) had a mean molecular weight of $21,000 \mathrm{Da}$ (polydispersity index I=1.8) as determined by size-exclusion chromatography (standard: polystyrene). Phosphate buffered saline (PBS) was purchased from Lonza biowhittaker $^{\circledR}$, Belgium. Dulbecco's modified eagle medium (DMEM) was provided by $\mathrm{Gibco}^{\circledR}$, Life Technology. Ultrapure water was obtained from a Milli- ${ }^{\circledR}$ Advantage A10 system (Millipore, Paris, France). All samples were lyophilized in Freeze-Dryer (Lyovax GT, Steris ${ }^{\circledR}$, France) for $18 \mathrm{~h}$.

\section{Methods}

Protein precipitation and encapsulation: Lysozyme precipitates, optimized by Giteau et al. [46], were used for the encapsulation of the protein. Precisely, $975 \mu \mathrm{l}$ of glycofurol (GF) was added to $25 \mu \mathrm{l}$ of 0.16 $\mathrm{M} \mathrm{NaCl}$ solution containing $500 \mu \mathrm{g}$ lysozyme to obtain a suspension of protein precipitates. TGF- $\beta 1$ was precipitated in similar method but adapted to this protein. Mixture of $120 \mu \mathrm{l} \mathrm{GF}$ and $75 \mu \mathrm{l}$ of isosorbide dimethyl ether (DMI) was added to $5 \mu \mathrm{l}$ of Tris- $\mathrm{HCl} 0.05 \mathrm{M}, \mathrm{NaCl} 2 \mathrm{M}$ solution $(\mathrm{pH}=7.4)$ containing $15 \% \mathrm{w} / \mathrm{v}$ Lutrol ${ }^{\circledR} \mathrm{F} 68$ and $10 \mu \mathrm{g}$ TGF- $\beta 1$ to obtain a suspension of protein precipitates. The encapsulation of protein was then performed as previously described in our paper [38]. Briefly, $100 \mu \mathrm{l}$ of the suspension of protein precipitates was added into $300 \mu \mathrm{l}$ of $12 \% \mathrm{w} / \mathrm{v}$ PLGA solution in GF to finally obtain a suspension of protein precipitates in polymer solution. This suspension was then gently mixed with $100 \mu \mathrm{l}$ of ethanol right before $1.5 \mathrm{ml}$ of $1 \%$ Lutrol $^{\mathrm{R}}$ F68 solution was added into this mixture to start the phase separation and thus to produce the nanoparticles. Thereafter, $15 \mathrm{ml}$ of $6 \%$ Lutrol $^{\circledR}$ F68 solution in $1.25 \mathrm{mM}$ glycine buffer (solution A) was introduced into the suspension of nanoparticles. After $15 \mathrm{~min}, 25 \mathrm{ml}$ of the solution A was added and the final suspension was left to stand for $16 \mathrm{~h}$ at room temperature $\left(\approx 25^{\circ} \mathrm{C}\right)$ for the extraction step. For the preparation of blank PLGA nanoparticles, $100 \mu$ of protein precipitates was replaced by $100 \mu \mathrm{l}$ of GF or mixture of GF and DMI. It should be noted that the $\mathrm{pH}$ of the solution $\mathrm{A}$ is 10.35 and 9 in the case of lysozyme and TGF- $\beta 1$ respectively. Finally, the suspension of nanoparticles was concentrated by centrifuging and then freeze-dried for further quantification.

Characterization of protein-loaded nanoparticles: The morphology of the nanoparticles was performed by transmission electron microscopy (TEM, JEOL, JEM1400, Japan). Drops of nanoparticle suspension diluted in ultrapure Milli- ${ }^{\circledR}$ water were deposited in carbon-coated copper grids and negatively stained with $1 \%$ phosphotungstic acid solution, the excess solution was blotted off using filter paper, and the grids were air dried before observation. Nanoparticle size was determined by dynamic light scattering and zeta potential was measured by electrophoretic light scattering principle using a Nanosizer ${ }^{\mathbb{B}}$ ZS (Malvern Instruments, Worcestershire, UK). Suspensions of nanoparticles diluted in ultrapure water to a suitable concentration were used for these analyses. Data analysis was performed in automatic mode at $25^{\circ} \mathrm{C}$. Measured size was presented as the average value of 20 runs, with triplicate measurements within each run.

\section{Quantification of the proteins}

Quantification of the model protein (lysozyme): The total amount of each batch of freeze-dried nanoparticles was dissolved in $1 \mathrm{ml}$ of DMSO (3 batches, 3 experiments per batch). After $1 \mathrm{~h}$ at room temperature, $3 \mathrm{ml}$ of $0.01 \mathrm{M} \mathrm{HCl}$ was added into the solution. The solution was left for an additional hour for protein extraction and then samples were taken for further analyses of total and bioactive lysozyme.

Total lysozyme quantification: Total lysozyme content in the nanoparticles was measured by micro-BCA protein Kit according to the manufacturer's procedure [47]. Briefly, samples were centrifuged at $10,000 \mathrm{~g}$ for $30 \mathrm{~min}$ to eliminate polymer precipitates and then 100 $\mu \mathrm{l}$ of supernatant were mixed with $100 \mu \mathrm{l}$ of BCA reagent in a 96-well microplate (Sterilin ${ }^{\circledR}$, Thermo-Fisher Scientific, France) and incubated at $37^{\circ} \mathrm{C}$ for $2 \mathrm{~h}$ away from light. Absorbance was finally measured at $580 \mathrm{~nm}$ with a plate reader (Multiskan Ascent ${ }^{\mathbb{R}}$, Labsystems, USA). A standard curve was used to calculate the protein concentration after subtraction of the control value of blank sample prepared in the same conditions as described in the previous section.

Active lysozyme quantification: The biologically active entrapped lysozyme was determined by measuring the protein activity in the presence of its substrate, Micrococcus lysodeikticus. Samples were diluted to an appropriate range of concentration before being incubated with $0.015 \%$ Micrococcus lysodeikticus suspension in Tris- $\mathrm{HCl}(0.05 \mathrm{M}$, $\mathrm{pH}$ 7.4) buffer solution at $37^{\circ} \mathrm{C}$ for $4 \mathrm{~h}$. Lysozyme activity determination was based on turbidity measurement at $450 \mathrm{~nm}$ on a spectrophotometer (Shimadzu, Japan). Amount of active protein was calculated using a standard curve.

\section{Quantification of the therapeutic protein (TGF- $\beta 1$ )}

Enzyme-linked immunosorbent assay (ELISA): As previously described, the total amount of each batch of freeze-dried protein-loaded nanoparticles was dissolved in $1 \mathrm{ml}$ of DMSO ( 3 batches, 3 experiments per batch). After one hour at room temperature, $3 \mathrm{ml}$ of $10 \mathrm{mM}$ citric acid was added into the solution. The solution was left for an additional hour for the protein extraction. Samples were diluted to an appropriate concentration using reagent diluent according to the manufacturer's procedure. TGF- $\beta 1$ was then quantified at room temperature using the corresponding ELISA Kit. Briefly, a plate (Nunc, polylabo, Strasbourg, France) was coated with capture antibody solution. After an overnight incubation, the plate was washed with PBS buffer, $0.05 \%$ Tween 20 and then blocked by adding PBS buffer, 5\% Tween 20 in each well for $1 \mathrm{~h}$. After washing, aliquots of standard solution and sample solution diluted in Kit reagent diluent were added and incubated for $2 \mathrm{~h}$. After washing, a detection antibody solution was added and incubated for $2 \mathrm{~h}$. The solution was then rinsed and a prepared streptavidin-HRP solution was added for $20 \mathrm{~min}$. Afterwards, the plate was washed and a substrate solution was added to each well for $20 \mathrm{~min}$. Finally, the reaction was stopped by $2 \mathrm{~N} \mathrm{H}_{2} \mathrm{SO}_{4}$ solution and the absorbance was measured at 450 $\mathrm{nm}$. The calibration curve was generated with appropriate Kit standard solution.

Bioactivity assay: In order to quantify bioactive TGF- $\beta 1$ released from nanoparticles, a bioassay was performed as previously described by Tesseur et al. [48]. This bioassay relies on the use of mouse fibroblasts isolated from TGF- $\beta 1^{-/}$mice (MFB-F11) stably transfected with a reporter plasmid consisting of TGF- $\beta$ responsive Smad-binding elements coupled to the secreted alkaline phosphatase (SEAP) reporter gene. Briefly, MFB-F11 fibroblasts were seeded in 96-well flat bottom plates at a density of $3 \times 10^{4}$ cells/well in $200 \mu \mathrm{l}$ of DMEM with $4.5 \mathrm{~g} / \mathrm{L}$ glucose and $10 \%$ fetal bovine serum (FBS). After an overnight incubation 
at $37^{\circ} \mathrm{C}$ and $5 \% \mathrm{CO}_{2}$, cells were washed twice with PBS and $100 \mu \mathrm{l}$ of serum-free DMEM was added to each well. After $2 \mathrm{~h}$ of incubation, 100 $\mu \mathrm{l}$ of the sample containing TGF- $\beta 1$ released from nanoparticles was added to the wells. To determine the standard curve, serial dilutions of TGF- $\beta 1$ were added to additional wells. After $24 \mathrm{~h}$ at $37^{\circ} \mathrm{C}$ and $5 \% \mathrm{CO}_{2}$, $50 \mu \mathrm{l}$ of supernatant was collected for each well in order to measure the SEAP activity using the SEAP Reporter Gene Assay, chemiluminescent kit according to the manufacturer's procedure (Roche Applied Science, Mannheim, Germany). The chemiluminescence was measured using a plate reader (Multiskan Ascent ${ }^{\circledR}$, Labsystems, USA).

Structural integrity of lysozyme after encapsulation: Different spectroscopic techniques were used to reveal any changes in the protein structure after encapsulation. Due to the detection limit of these methods $(0.06 \mathrm{mg} / \mathrm{ml})$, only structure integrity of lysozyme was assessed.

Circular dichroism spectroscopy: Circular dichroism (CD) spectra were recorded on a J-810 CD spectrometer (Jasco, Japan) in step mode (bandwidth: $2 \mathrm{~nm}$; interval: $0.1 \mathrm{~nm}$; response time: $0.125 \mathrm{~s}$ ). The CD data were collected from 200 to $260 \mathrm{~nm}$ using a mini-quartz cell (Hellma, Germany) with $0.2 \mathrm{~cm}$ path length and averaged over 5 scans to increase the signal to noise ratio. The temperature of measurement was controlled with a Peltier-effect temperature controller, and was usually $20^{\circ} \mathrm{C}$. At least three $\mathrm{CD}$ spectra were monitored for each sample and were scaled in units of milli-degrees (mdeg). The spectra were then averaged and smoothed using a 13-point fast fourier transform (FFT) algorithm (spectra manager software).

UV-spectroscopy in the fourth derivative mode: Baselinecorrected absorbance spectra in the range of 260-330 nm were recorded at $37^{\circ} \mathrm{C}$ using a V-530 Jasco UV/Vis spectrophotometer. Data acquisition was in steps of $1 \mathrm{~nm}$ with an acquisition time of $1 \mathrm{~s}$ per data point. The fourth derivatives of the UV spectra were calculated with Spectra Manager analysis software (Jasco, Japan) to improve the low resolution of zero-order spectra and provide information about structural changes of proteins in the local environment of tyrosine and tryptophan residues.

Fluorescence spectroscopy: Spectra were recorded on a FP-6500 spectrofluorometer (Jasco, Japan) equipped with a Peltier temperature controller. The emission spectra were measured (bandwidth: $5 \mathrm{~nm}$ : response time: $0.5 \mathrm{~s}$; scan rate: $100 \mathrm{~nm} / \mathrm{min}$; data pitch: $0.1 \mathrm{~nm}$ ) in a 0.2 $\mathrm{x} 1 \mathrm{~cm}$ mini cell (Hellma, Germany) at $25^{\circ} \mathrm{C}$. The excitation wavelength was $295 \mathrm{~nm}$ for selective excitation of the tryptophan residue. The spectra were measured three times from 310 to $450 \mathrm{~nm}$ and the data were averaged to increase the signal-to-noise ratio. All the spectra were corrected for the Raman signal and background by subtracting the spectrum of the vehicle solution.

Residual glycofurol quantification: Residual glycofurol content was analyzed in blank PLGA nanoparticles using a previously described protocol [41]. The entire batch was first dissolved in $1 \mathrm{ml}$ of acetone (3 batches, 3 experiments per batch). The polymer was then precipitated by $4 \mathrm{ml}$ of distilled water. Afterwards, the suspension was centrifuged at $10,000 \mathrm{~g}$ for $30 \mathrm{~min}$, and the supernatant was collected for further analysis. Four millimeters of an ammonium cobaltothiocyanate reagent solution and $4 \mathrm{ml}$ of methylene chloride were added to the sample. Thereafter, this mixture was centrifuged, and the methylene chloride phase was extracted to quantify residual glycofurol by measuring the absorbance at $620 \mathrm{~nm}$ on a spectrophotometer (Shimadzu, Japan).

Protein release study: Protein-loaded nanoparticle suspension of an entire batch was put inside a dialysis bag with a 1,000 kDa molecular weight cut-off (Spectrum laboratories, Inc., Rancho Dominguez, CA) and placed in a beaker containing $80 \mathrm{ml}$ of $0.05 \mathrm{M}$ Tris- $\mathrm{HCl}$ buffer, $\mathrm{pH}$ $7.4,0.1 \% \mathrm{w} / \mathrm{v}$ BSA in the case of lysozyme and $80 \mathrm{ml}$ of PBS buffer, $\mathrm{pH}$ $7.4,1 \% \mathrm{w} / \mathrm{v}$ BSA in the case of TGF- $\beta 1$. The beaker was closed and placed in a water bath at $37^{\circ} \mathrm{C}$ under stirring. At specific time intervals, samples from release medium were withdrawn and the whole medium was replaced with fresh one. Due to the detection limit of the quantification method, only bioactive lysozyme released from nanoparticles over 15 days was assessed. In the contrary, released TGF- $\beta 1$ was quantified by ELISA and bioassay over 30 days. The experiments were made in triplicate. The ratio of cumulative release was calculated based on the amount of protein obtained from the encapsulation efficiency.

In vitro cytocompatibility of unloaded PLGA nanoparticles: Cytotoxicity evaluation of unloaded nanoparticles was performed using MTS assay which measures the reduction of tetrazolium salts caused by mitochondrial dehydrogenases of viable cells to water-soluble formazan product. Briefly, NIH3T3 mouse cell line, HS68 human fibroblasts and human adipose tissue stem cells (hATSC) were seeded in 24-well plates at $37^{\circ} \mathrm{C}$ in a $5 \% \mathrm{CO}_{2}$ incubator with a final cell density of $15 \times 10^{3}$ cells $/ \mathrm{cm}^{2}$. After $24 \mathrm{~h}$, the culture medium was changed with unloaded nanoparticle suspension in stabilizer solution (Lutrol ${ }^{\circledR}$ F68) after dilution with culture medium to an appropriate concentration (0.1-20 $\mathrm{mg} / \mathrm{ml}$ ). As a control, cells were cultured in the absence of nanoparticle suspension. The cultures were further incubated for $48 \mathrm{~h}$, and then NP suspension in the culture medium was entirely removed by several PBS washes followed by the addition of MTS reagent solution to each well for $1 \mathrm{~h}$. The absorbance of resulting blue formazan was measured with a plate reader at $490 \mathrm{~nm}$ (MultiskanAscent ${ }^{\mathbb{B}}$, Labsystems, USA). Each experiment was realized in triplicate. The relative cell viability was calculated as the ratio of the mean of optical density obtained for the sample to that of the control. Furthermore, the viability assay was used to assess the cytotoxicity of the stabilizer used for the preparation of nanoparticles suspension. Stabilizer solutions in cell culture medium were appropriately diluted to a concentration corresponding to the amount present in the Nanoparticle suspension. Values are expressed in mean \pm standard deviation (SD). The differences between treated and untreated cells were evaluated using one-way ANOVA test.

\section{Results and Discussion}

\section{Encapsulation of the proteins into PLGA nanoparticles}

Many studies showed that protein stability in contact with organic solvents is enhanced when the protein is in a solid-state because of the decrease in its conformational mobility in the absence of water $[3,46]$. Therefore, in this paper proteins were first precipitated to ensure their stability using non-toxic injectable solvents GF and DMI [38]. The protein precipitates were then encapsulated within PLGA nanoparticles by a phase separation method called nanoprecipitation. During the encapsulation step, the $\mathrm{pH}$ of dispersing phase was buffered to be near to the protein isoelectric point $(\mathrm{Pi})$. In our previous study, we have demonstrated the impact of aqueous phase $\mathrm{pH}$ on the protein encapsulation efficiency [38]. Govender et al. also reported the influence of aqueous phase $\mathrm{pH}$ on the drug entrapment [49]. It is hypothesized that the protein is less ionized at $\mathrm{pH}$ near its $\mathrm{Pi}$ and therefore less soluble in the aqueous phase than in the organic phase. This may reduce the protein leakage into the aqueous phase and thus increase the encapsulation efficiency. The mean encapsulation efficiency was $76 \pm 5 \% ; 73 \pm 6 \%$ for total and active lysozyme respectively. These results emphasize high preserved activity (96\%) of the total amount of lysozyme encapsulated by our process. In the case of the therapeutic 


\begin{tabular}{|c|c|c|c|c|}
\hline Batch & $\mathrm{EE} \pm \mathrm{SD}(\%)$ & Size \pm SD $(n m)$ & $\mathrm{PI} \pm \mathrm{SD}$ & Zeta potential \pm SD $(\mathrm{mV})$ \\
\hline Lysozyme-loaded NPs & $76 \pm 5$ & $381 \pm 68$ & $0.14 \pm 0.05$ & $-29 \pm 2.6$ \\
\hline TGF- $\beta 1$-loaded NPs & $50 \pm 7$ & $345 \pm 35$ & $0.13 \pm 0.03$ & $-28 \pm 1.3$ \\
\hline
\end{tabular}

*EE: encapsulation efficiency; SD: standard deviation; PI: mean polydispersity index expressed using a 0-1 scale $(n=3)$

Table 1: Characterization of PLGA nanoparticles prepared by the phase separation method*

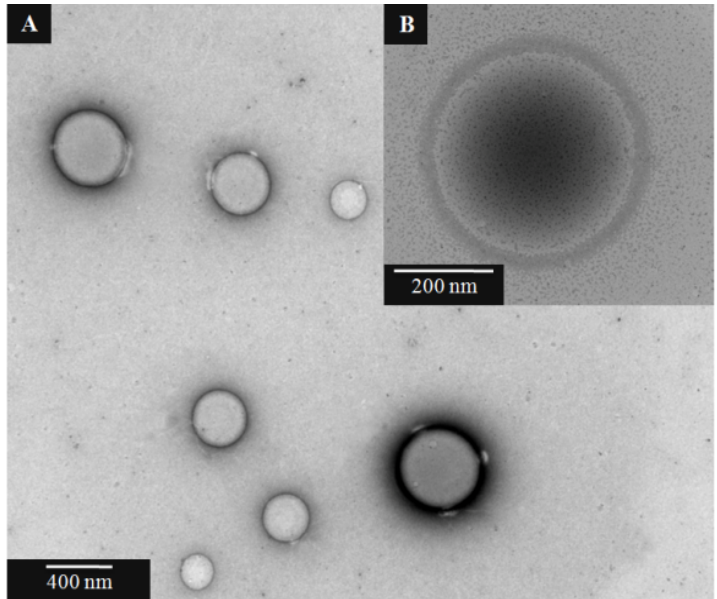

Figure 1: TEM images of nanoparticles (A), and at high magnification (B).
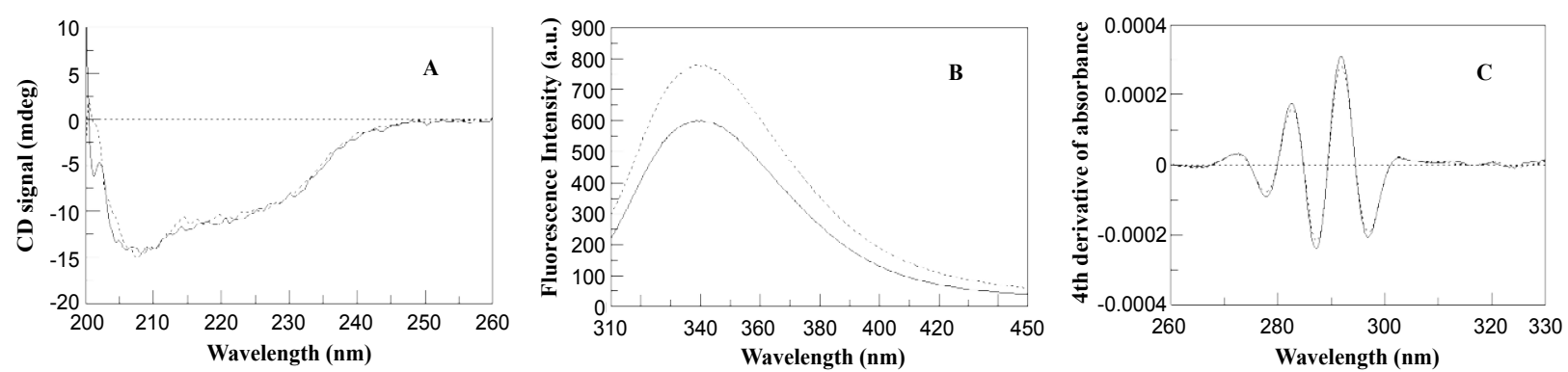

Figure 2: Results of spectroscopic studies of native lysozyme (solid curve) and encapsulated lysozyme (dotted curve).The far-UV CD, fluorescence and fourth derivative of UV spectra are shown in panel $A, B$ and $C$ respectively.

protein (TGF- $\beta 1$ ) the encapsulation efficiency determined by ELISA was $50 \pm 7 \%$ (Table 1$)$.

\section{Characterization of protein-loaded nanoparticles}

The results of the TEM observation showed that the prepared nanoparticles were spherical in shape and of submicron size (Figure 1). This was further confirmed by nanoparticle size analysis using Nanosizer, which showed that the average size is about $345-381 \mathrm{~nm}$ with satisfactory polydispersity index (Table 1). These results are in agreement with those obtained by Bilati et al. in which non-volatile water-miscible solvents like DMSO were used to dissolve PLGA. Nanoparticles were also formed by a nanoprecipitation process when polymer solution was mixed with a non-solvent such as water, propanol or ethanol [4]. Zeta potential measurements showed that PLGA nanoparticles had a negative surface charge of about $-28 \mathrm{mV}$ (Table 1) which could be attributed to the presence of terminal carboxylic groups of the polymer on the nanoparticle surface. Comparable results were reported in several other studies [50,51].

\section{Lysozyme structural integrity study}

Different spectroscopic methods were performed to assess the structural integrity of the lysozyme after encapsulation. The structure of released lysozyme from the nanoparticles was compared to that of the native protein prepared in the same conditions (free protein as reference). Generally, if a protein becomes denatured during the encapsulation step, it will remain in the same state during the release step. Therefore, samples of lysozyme released within $24 \mathrm{~h}$ from nanoparticles into a PBS solution containing $0.1 \% \mathrm{w} / \mathrm{v}$ Lutrol $\mathrm{F} 68^{\circledR}\left(\mathrm{pH} 7.4,37^{\circ} \mathrm{C}\right)$ was collected and concentrated using Amicon ${ }^{\circledR}$ ultra centrifugal filters (Ultracel ${ }^{\mathbb{B}}-3 \mathrm{KDa}$, Germany) to obtain the concentration of $0.06 \mathrm{mg} / \mathrm{ml}$. Secondary structure of each protein was analyzed by $\mathrm{CD}$ measurement. The comparison between released and free lysozyme CD spectra was performed. The Figure 2A showed that the secondary structure of both proteins was unchanged and thus preserved upon and after encapsulation.

Fluorescence spectroscopy spectra showed a reduced level of fluorescence intensity without change in peak maximum which is possibly due to a quenching of the fluorescence rather than changes in the protein integrity (Figure 2B). These results were confirmed with the fourth derivative UV-visible spectra which did not show any shift of maxima in the area corresponding to tyrosine and tryptophan residues 

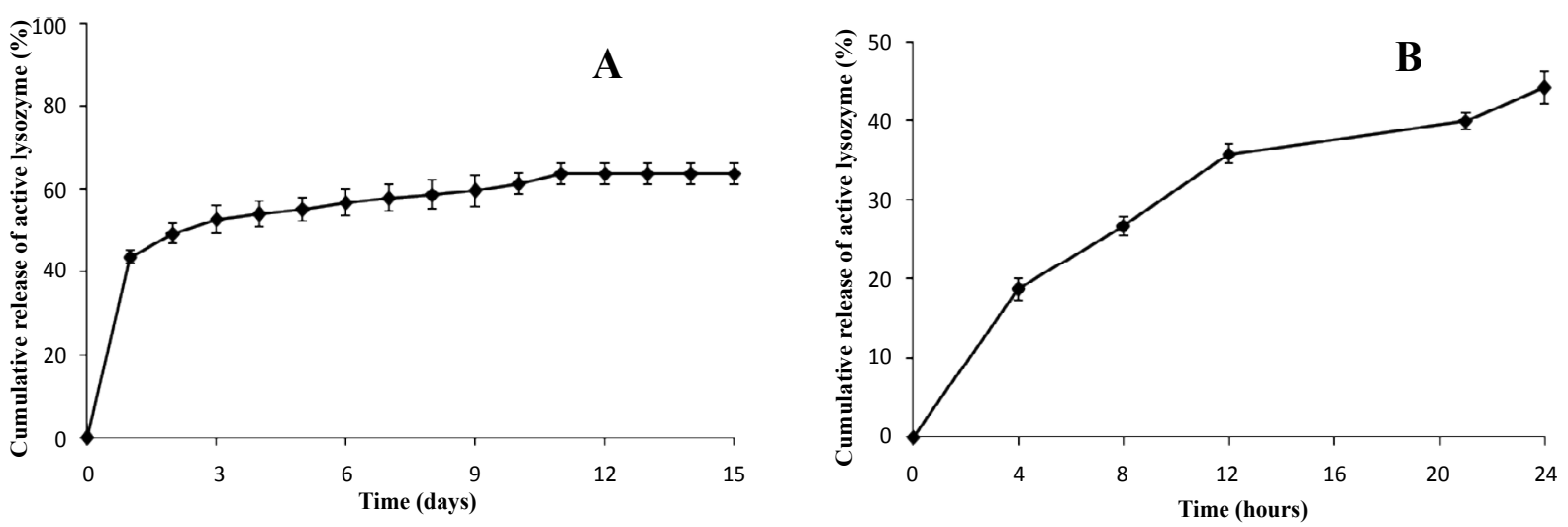

Figure 3: In vitro release profile of active lysozyme during 15 days (A), and during the first $24 \mathrm{~h}(\mathrm{~B})$.
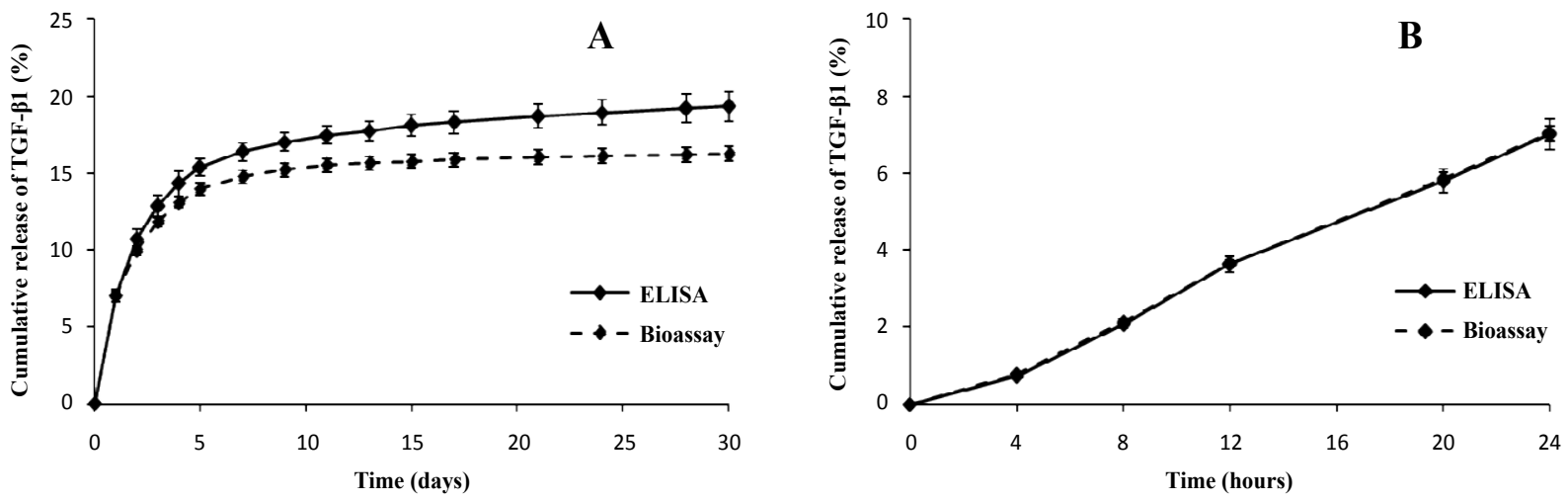

Figure 4: In vitro release profile of TGF- $\beta 1$ during 30 days (A), and during the first $24 \mathrm{~h}(\mathrm{~B})$.

(284 and $290 \mathrm{~nm}$ respectively) indicating no change in the secondary structure after encapsulation (Figure 2C).

\section{Residual glycofurol content}

Residual glycofurol content is of $14.2 \pm 1.3 \mathrm{mg}$ per $100 \mathrm{mg}$ nanoparticles. In our previous paper [38], the presence of residual glycofurol was assessed using DSC analysis (Differential scanning calorimetry) by the decrease of PLGA transition temperatures from around $45^{\circ} \mathrm{C}$ to around $27.5^{\circ} \mathrm{C}$. Comparable results were found by Allhenn et al. [41]. Non-volatile solvents are generally more difficult to extract compared to volatile ones. In spite of the incomplete solvent extraction, no loss of protein integrity or bioactivity was detected as described above. Furthermore, lysozyme stability was tested in glycofurol at $24^{\circ} \mathrm{C}$ by Aubert-Pougëssel et al. and results showed that $100 \%$ of biologically active protein was recovered [52].

\section{In vitro release study of the protein from nanoparticles}

The release profiles of lysozyme and TGF- $\beta 1$ from nanoparticles are shown in Figures $3 \mathrm{~A}$ and $4 \mathrm{~A}$. Both proteins were released in a biphasic mode. The first phase is characterized by a fast release which probably results from the solubilization of protein that usually exists near the surface. The second phase is characterized by a slow release which could be attributed to the degradation of polymer matrix leading to the diffusion of the entrapped protein. Similar profiles of protein release are found in the literature for such nano-sized systems [53-55].
The extents of lysozyme and TGF- $\beta 1$, released in the first day, were about $44 \%$ and $7 \%$ respectively (Figures $3 \mathrm{~B}$ and $4 \mathrm{~B}$ ). These results are believed to be related to the fact that lysozyme has a higher quantity of loaded protein than TGF- $\beta 1$ ( $50 \mu \mathrm{g}$ and $5 \mu \mathrm{g}$ respectively for $36 \mathrm{mg}$ of PLGA theoretically) and thus a higher initial release. Probably, with the increase in drug loading, a large protein gradient is formed within particles toward release medium which induces a faster drug release and consequently a higher burst effect [56]. On the other hand, the release rate of lysozyme from nanoparticles was higher than that of TGF- $\beta 1$ over 15 days ( $64 \%$ and $18 \%$ respectively, Figures $3 \mathrm{~A}$ and $4 \mathrm{~A}$ ), which indicates that release kinetics of the proteins from nanoparticles are influenced by the physicochemical characteristic of each protein (Lysozyme: pi=11, MW=14 kDa, TGF- $\beta 1$ : pi=8.6, MW=25 kDa). Due to its higher molecular weight, TGF- $\beta 1$ has likely less diffusion rate and more interaction with the polymer matrix than lysozyme and thus a lower release rate. Interestingly, the amount of total TGF- $\beta 1$ released after $24 \mathrm{~h}$ quantified by ELISA is equal to that of active protein quantified by bioassay (Figure 4B). This result confirms that the biological activity of TGF- $\beta 1$ was preserved after encapsulation. Similar results were also obtained for lysozyme as previously described indicating the versatility of our method for protein encapsulation. After $24 \mathrm{~h}$ of release study, PLGA nanoparticles were recovered and freeze-dried to quantify the remaining active lysozyme. $56 \%$ of active lysozyme was found to be remaining in each sample. While the released active lysozyme added to the remaining active protein is equal to $100 \%$ after $24 \mathrm{~h}$, it is not the case after 15 days where about $12 \%$ of active lysozyme was found 


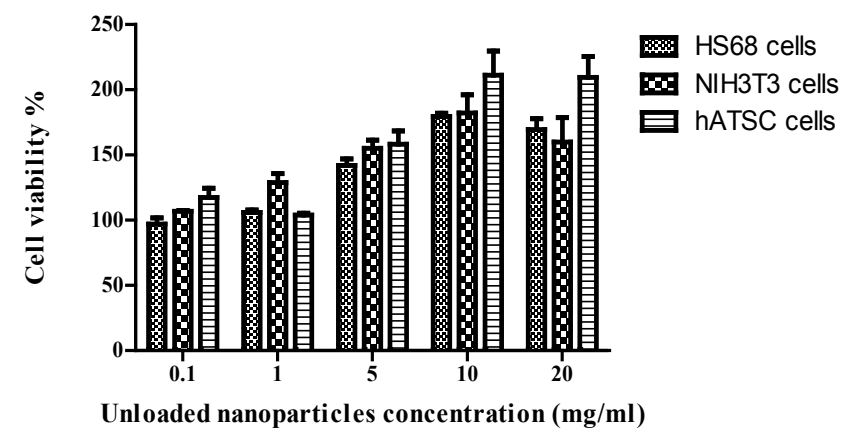

Figure 5: Effect of unloaded PLGA nanoparticles on percentage viability of NIH3T3, HS68 and hATSC cells after $48 \mathrm{~h}$ of incubation as shown by a MTS assay.

to be remaining inside the nanoparticles, which means that $24 \%$ of the total amount of active lysozyme was denatured. Similar results were observed for TGF- $\beta 1$ quantified by ELISA. After $24 \mathrm{~h}$, the total amount of TGF- $\beta 1$ (released amount added to remaining amount) is equal to $100 \%$ whilst after 15 days, about $36 \%$ of the total amount was denatured. Thus, we believe that protein denaturation occurs inside the nanoparticles during the release step since we have proven in a preliminary study that both proteins are stable in the release medium. However, over the whole time of release study, bioactive released TGF- $\beta 1$ quantified by bioassay represented $84 \%$ of the total amount of released TGF- $\beta 1$ quantified by ELISA which is also supposed to be related to the protein denaturation inside the nanoparticles during the release step. It should be noted that Lutrol ${ }^{\circledR}$ F68 was used during the precipitation step in the case of TGF- $\beta 1$ to enhance its stability in the polymer matrix and thus improving its release as described in many studies [57,58]. However, an incomplete release was observed for each protein. These findings was reported earlier in the literature $[59,60]$ and could be prone to many denaturation mechanisms such as nonspecific adsorption onto the polymer, acid-induced aggregation due to polymer degradation, and moisture-induced aggregation [61,62]. Many strategies have been proposed by different authors to improve protein stability within PLGA particles during the release step [63,64]. In order to minimize protein adsorption and to enhance water uptake and thereby promoting the release rate, pegylated PLGA or a blend of PEG and PLGA were used [16,65]. Basic salts such as zinc carbonate and magnesium compounds were proposed to inhibit acid-induced protein degradation inside the polymeric particles during the release [66,67]. Other additives like ammonium sulphate were also used to minimize moisture-induced protein aggregation during slow PLGA particles hydration [68]. These approaches are now under investigation and would be considered in a future work.

\section{Cytocompatibility study}

The safety of PLGA particles as drug delivery systems is very important for medical applications. However, PLGA nanoparticles are well known to be biodegradable and biocompatible in vitro and in vivo compared to other nanoparticles of a similar size range such as zinc oxide, ferrous oxide and fumed silica which exhibit toxic effects when applied in the field of nanomedicine $[69,70]$.

An in vitro cytotoxicity study was conducted to assess the cell viability following exposure to the unloaded PLGA nanoparticles, NIH3T3, HS68 and hATSC cells were cultured in the presence of unloaded PLGA nanoparticles. MTS assay showed excellent cell viability even at high nanoparticles concentration $(20 \mathrm{mg} / \mathrm{ml})$ (Figure 5). Furthermore, the cells viability in NP suspension was comparable to that in stabilizer solution (Lutrol ${ }^{\circledR} \mathrm{F} 68$ ) at a concentration corresponding to the amount present in the nanoparticle suspension (data not shown). These results confirm the cytocompatibility of PLGA nanoparticles which are in agreement with data obtained earlier in the literature [71-73]. It should be noted that the proliferation of cells was observed after 48 $\mathrm{h}$ of incubation with unloaded NPs starting from concentration of 5 $\mathrm{mg} / \mathrm{ml}$. Various parameters might affect the cell proliferation such as the methodology of NP formulation, residual solvent and cell lines type. However, more specific assays on cell proliferation, such as assays based on DNA quantification, should be considered in future work in order to confirm this effect. In this experiment, our goal was to assess the cytocompatibility of obtained nanoparticles which will be used for tissue engineering applications where the effect on cell proliferation might be of interest.

\section{Conclusion}

In this study, protein-loaded nanoparticles were prepared using non-toxic solvents by a novel phase separation method based on a preliminary step of protein precipitation. Interestingly, structural integrity and biological activity of the encapsulated proteins were preserved and good encapsulation efficiencies were also achieved. Sustained released of the proteins from the prepared nanoparticles was assessed. Nevertheless, the optimization of protein release is still in progress. This work can serve as an alternative for classic encapsulation methods which use volatile toxic solvents. Further efforts will be provided for the development of the final product in the form of hybrid biomaterials for regenerative medicine application. Therefore, the potential of these polymeric systems to allow proliferation and differentiation of chondrocytes in vitro will be firstly assessed in a future work. Then, TGF- $\beta 1$-loaded PLGA nanoparticles could be combined to a hydrogel containing adult stem cells as an implantable synthetic extracellular matrix for cartilage regeneration. In addition to the interest of obtained nanoparticles for tissue engineering, their application can be extended to any domain requiring protein encapsulation.

\section{Acknowledgment}

Acknowledgments are made to the SCIAM ("Service Commun d'Imagerie et d'Analyse Microscopique") for transmission electron microscope images. We thank the "Région Pays de la Loire" (Bioregos 2 project), ANR ("Agence Nationale pour la Recherche", grant (ANR-09-PIRI-0004-01), the French and Syrian education ministers for the financial support.

\section{References}

1. Sánchez A, Tobío M, González L, Fabra A, Alonso MJ (2003) Biodegradable micro- and nanoparticles as long-term delivery vehicles for interferon-alpha. Eur J Pharm Sci 18: 221-229.

2. Sinha VR, Trehan A (2003) Biodegradable microspheres for protein delivery. J Control Release 90: 261-280

3. Morales-Cruz M, Flores-Fernández GM, Morales-Cruz M, Orellano EA, Rodriguez-Martinez JA, et al. (2012) Two-step nanoprecipitation for the production of protein-loaded PLGA nanospheres. Results Pharma Sci 2: 79-85.

4. Bilati U, Allémann E, Doelker E (2005) Nanoprecipitation versus emulsion-based techniques for the encapsulation of proteins into biodegradable nanoparticles and process-related stability issues. AAPS PharmSciTech 6: E594-604.

5. Gander B, Johansen H, Tran N, Merkle H (1996) Thermodynamic approach to protein microencapsulation into poly( $\mathrm{D}, \mathrm{L}$-lactide) by spray drying. International Journal of Pharmaceutics 129: 51-61.

6. Lam XM, Duenas ET, Daugherty AL, Levin N, Cleland JL (2000) Sustained release of recombinant human insulin-like growth factor-I for treatment of diabetes. J Control Release 67: 281-292.

7. De Rosa G, Larobina D, Immacolata L, Rotonda M, Quaglia F, et al. (2005) How cyclodextrin incorporation affects the properties of protein-loaded PLGA-based 
microspheres: the case of insulin/hydroxypropyl-ß-cyclodextrin system. Journal of Controlled Release 102: 71-83.

8. Thomasin C, Merkle H, Gander B (1998) Drug microencapsulation by PLA PLGA coacervation in the light of thermodynamics. 2. Parameters determining microsphere formation. Journal of Pharmaceutical Sciences 87: 269-275.

9. Thomasin C, Merkle H, Gander BA (1997) Physico-chemical parameters governing protein microencapsulation into biodegradable polyesters by coacervation. International Journal of Pharmaceutics 147: 173-186.

10. White LJ, Kirby GT, Cox HC, Qodratnama R, Qutachi O, et al. (2013) Accelerating protein release from microparticles for regenerative medicine applications. Mater Sci Eng C Mater Biol Appl 33: 2578-2583.

11. Manoharan C, Singh J (2009) Insulin loaded PLGA microspheres: effect of zinc salts on encapsulation, release, and stability. J Pharm Sci 98: 529-542.

12. Lagarce F, Garcion E, Faisant N, Thomas O, Kanaujia P, et al. (2006) Development and characterization of interleukin-18-loaded biodegradable microspheres. Int J Pharm 314: 179-188.

13. Marquette S, Peerboom C2, Yates A2, Denis L2, Goole J3, et al. (2014) Encapsulation of immunoglobulin $\mathrm{G}$ by solid-in-oil-in-water: effect of process parameters on microsphere properties. Eur J Pharm Biopharm 86: 393-403.

14. Andreas K, Zehbe R, Kazubek M, Grzeschik K, Sternberg N, et al., (2011) Biodegradable insulin-loaded PLGA microspheres fabricated by three different emulsification techniques: Investigation for cartilage tissue engineering. Acta Biomaterialia 7: 1485-1495.

15. Yuan W, Wu F, Guo M, Jin T (2009) Development of protein delivery microsphere system by a novel S/O/O/W multi-emulsion. Eur J Pharm Sci 36: 212-218.

16. Lochmann A, Nitzsche H, von Einem S, Schwarz E, Mäder K (2010) The influence of covalently linked and free polyethylene glycol on the structural and release properties of rhBMP-2 loaded microspheres. Journal of Controlled Release 147: 92-100.

17. Buske J, König C, Bassarab S, Lamprecht A, Mühlau S, et al. (2012) Influence of PEG in PEG-PLGA microspheres on particle properties and protein release. Eur J Pharm Biopharm 81: 57-63.

18. Cho M, Sah H (2005) Formulation and process parameters affecting protein encapsulation into PLGA microspheres during ethyl acetate-based microencapsulation process. J Microencapsul 22: 1-12.

19. Sah $H$ (2000) Ethyl formate - alternative dispersed solvent useful in preparing PLGA microspheres. Int J Pharm 195: 103-113.

20. Sah H, Smith MS, Chern RT (1996) A novel method of preparing PLGA microcapsules utilizing methylethyl ketone. Pharm Res 13: 360-367.

21. Matsumoto A, Kitazawa T, Murata J, Horikiri Y, Yamahara H (2008) A novel preparation method for PLGA microspheres using non-halogenated solvents. J Control Release 129: 223-227.

22. Ghaderi R, Artursson P, Carlfors J (2000) A new method for preparing biodegradable microparticles and entrapment of hydrocortisone in dl-PLG microparticles using supercritical fluids. European Journal of Pharmaceutical Sciences 10: 1-9.

23. Whitaker MJ, Hao J, Davies OR, Serhatkulu G, Stolnik-Trenkic S, et al. (2005) The production of protein-loaded microparticles by supercritical fluid enhanced mixing and spraying. J Control Release 101: 85-92.

24. Mottu F, Stelling MJ, Rüfenacht DA, Doelker E (2001) Comparative hemolytic activity of undiluted organic water-miscible solvents for intravenous and intraarterial injection. PDA J Pharm Sci Technol 55: 16-23.

25. Mottu F, Laurent A, Rufenacht DA, Doelker E (2000) Organic solvents fo pharmaceutical parenterals and embolic liquids: a review of toxicity data. PDA J Pharm Sci Technol 54: 456-469.

26. Laurent A, Mottu F, Chapot R, Qi Zhang J, Jordan O, et al. (2007) Cardiovascular Effects of Selected Water-miscible Solvents for Pharmaceutical Injections and Embolization Materials: A Comparative Hemodynamic Study Using a Sheep Model. PDA Journal of Pharmaceutical Science and Technology, 61: 64-74.

27. Dudeck O, Jordan O, Hoffmann KT, Okuducu AF, Tesmer K, et al. (2006) Organic solvents as vehicles for precipitating liquid embolics: A comparative angiotoxicity study with superselective injections of swine rete mirabile. American Journal of Neuroradiology 27: 1900-1906.
28. Boongird A, Nasongkla N, Hongeng S, Sukdawong N, Sa-Nguanruang W, et al. (2011) Biocompatibility study of glycofurol in rat brains. Exp Biol Med (Maywood) 236: 77-83.

29. Mottu F, Gailloud P, Massuelle D, Rüfenacht DA, Doelker E (2000) In vitro assessment of new embolic liquids prepared from preformed polymers and water-miscible solvents for aneurysm treatment. Biomaterials 21: 803-811.

30. Barakat NS (2010) Evaluation of glycofurol-based gel as a new vehicle for topical application of naproxen. AAPS PharmSciTech 11: 1138-1146.

31. Nasongkla N, Boongird A, Hongeng S, Manaspon C, Larbcharoensub N (2012) Preparation and biocompatibility study of in situ forming polymer implants in rat brains. J Mater Sci Mater Med 23: 497-505.

32. Bechgaard E, Gizurarson S, Hjortkjær RK, Sørensen AR (1996) Intranasa administration of insulin to rabbits using glycofurol as an absorption promoter. International Journal of Pharmaceutics 128: 287-289.

33. Koocheki S, Madaeni SS, Niroomandi (2011) Application of hydroxyapatite nanoparticles in development of an enhanced formulation for delivering sustained release of triamcinolone acetonide. International Journal of Nanomedicine 6: 825-833.

34. Gizurarson S, Georgsson G, Aggerbeck H, Thorarinsdóttir H, Heron I (1996) Evaluation of local toxicity after repeated intranasal vaccination of guinea-pigs. Toxicology 107: 61-68

35. Luzzi LA, Joseph KH Ma (1980) Dimethyl isosorbide in liquid formulation of aspirin.

36. Otto A, Wiechers JW, Kelly CL, Hadgraft J, du Plessis J (2008) Effect of penetration modifiers on the dermal and transdermal delivery of drugs and cosmetic active ingredients. Skin Pharmacol Physiol 21: 326-334.

37. Crotty BA, Johnson A, Znaiden A (1998) Activity enhancement of ferulic acid with dimethyl isosorbride in cosmetic compositions.

38. Tran MK, Swed A, Boury F (2012) Preparation of polymeric particles in $\mathrm{CO}(2)$ medium using non-toxic solvents: formulation and comparisons with a phase separation method. Eur J Pharm Biopharm 82: 498-507.

39. Tran MK, Hassani LN, Calvignac B, Beuvier T, Hindré F, et al. (2013) Lysozyme encapsulation within PLGA and $\mathrm{CaCO} 3$ microparticles using supercritical $\mathrm{CO} 2$ medium. The Journal of Supercritical Fluids 79: 159-169.

40. Viehof A, Javot L, Béduneau A, Pellequer Y, Lamprecht A (2013) Oral insulin delivery in rats by nanoparticles prepared with non-toxic solvents. Int J Pharm 443: 169-174.

41. Allhenn D, Lamprecht $A$ (2011) Microsphere preparation using the untoxic solvent glycofurol. Pharm Res 28: 563-571.

42. Aubert-Pouëssel A, Venier-Julienne MC, Saulnier, Sergent M, Benoît J (2004) Preparation of PLGA Microparticles by an Emulsion-Extraction Process Using Glycofurol as Polymer Solvent. Pharmaceutical Research 21: 2384-2391.

43. Nimni ME (1997) Polypeptide growth factors: targeted delivery systems. Biomaterials 18: 1201-1225.

44. DeFail AJ, Chu CR, Izzo N, Marra KG (2006) Controlled release of bioactive TGF-beta 1 from microspheres embedded within biodegradable hydrogels. Biomaterials 27: 1579-1585.

45. Kim SE, Park JH, Cho YW, Chung H, Jeong SY, et al. (2003) Porous chitosan scaffold containing microspheres loaded with transforming growth factor- $\beta 1$ : Implications for cartilage tissue engineering. Journal of Controlled Release 91 : 365-374.

46. Giteau A, Venier-Julienne MC, Marchal S, Courthaudon JL, Sergent M, et al. (2008) Reversible protein precipitation to ensure stability during encapsulation within PLGA microspheres. European Journal of Pharmaceutics and Biopharmaceutics 70: 127-136

47. Smith PK, Krohn RI, Hermanson GT, Mallia AK, Gartner FH, et al. (1985) Measurement of protein using bicinchoninic acid. Analytical Biochemistry 150 $76-85$

48. Tesseur I, Zou K, Berber E, Zhang H, Wyss-Coray T (2006) Highly sensitive and specific bioassay for measuring bioactive TGF-beta. BMC Cell Biol 7: 15.

49. Govender T, Stolnik S, Garnett MC, Illum L, Davis SS (1999) PLGA nanoparticles prepared by nanoprecipitation: drug loading and release studies of a water soluble drug. J Control Release 57: 171-185. 
Citation: Swed A, Cordonnier T, Fleury F, Boury F (2014) Protein Encapsulation into PLGA Nanoparticles by a Novel Phase Separation Method Using Non-Toxic Solvents. J Nanomed Nanotechnol 5: 241. doi: 10.4172/2157-7439.1000241

50. Fonseca C, Simões S, Gaspar R (2002) Paclitaxel-loaded PLGA nanoparticles: preparation, physicochemical characterization and in vitro anti-tumoral activity. Journal of Controlled Release 83: 273-286.

51. Vega E, Egea MA, Valls O, Espina M, García ML (2006) Flurbiprofen loaded biodegradable nanoparticles for ophtalmic administration. J Pharm Sci 95: 2393-2405.

52. Aubert-Pouessel A, Venier-Julienne MC, Saulnier, Sergent M, Benoit J (2004) Preparation of PLGA microparticles by an emulsion-extraction process using glycofurol as polymer solvent. Pharmaceutical Research 21: 2384-2391.

53. Menon JU, Ravikumar P2, Pise A, Gyawali D, Hsia CC3, et al. (2014) Polymeric nanoparticles for pulmonary protein and DNA delivery. Acta Biomater 10: 26432652.

54. Li Y, Pei Y, Zhang X, Gu Z, Zhou Z, et al. (2001) PEGylated PLGA nanoparticles as protein carriers: synthesis, preparation and biodistribution in rats. $\mathrm{J}$ Control Release 71: 203-211.

55. Kumar PS, Saini TR, Chandrasekar D, Yellepeddi VK, Ramakrishna S, et al. (2007) Novel approach for delivery of insulin loaded poly(lactide-co-glycolide) nanoparticles using a combination of stabilizers. Drug Deliv 14: 517-523.

56. Yeo Y, Park K (2004) Control of encapsulation efficiency and initial burst in polymeric microparticle systems. Arch Pharm Res 27: 1-12.

57. Morille M, Van-Thanh T, Garric X, Cayon J, Coudane J, et al. (2013) New PLGA-P188-PLGA matrix enhances TGF- $\beta 3$ release from pharmacologically active microcarriers and promotes chondrogenesis of mesenchymal stem cells. J Control Release 170: 99-110.

58. Paillard-Giteau A, Tran VT, Thomas O, Garric X, Coudane J, et al. (2010) Effect of various additives and polymers on lysozyme release from PLGA microspheres prepared by an s/o/w emulsion technique. Eur J Pharm Biopharm 75: 128-136

59. Panyam J, Dali MM, Sahoo SK, Ma W, Chakravarthi SS, et al. (2003) Polymer degradation and in vitro release of a model protein from poly $(\mathrm{D}, \mathrm{L}-$ lactide-coglycolide) nano- and microparticles. J Control Release 92: 173-187.

60. Sahoo SK, Panyam J, Prabha S, Labhasetwar V (2002) Residual polyviny alcohol associated with poly (d,I-lactide-co-glycolide) nanoparticles affects their physical properties and cellular uptake. Journal of Controlled Release 82: 105114

61. Giteau A, Venier-Julienne MC, Aubert-Pouëssel A, Benoit JP (2008) How to achieve sustained and complete protein release from PLGA-based microparticles? Int J Pharm 350: 14-26.
62. Taluja A, Youn YS, Bae YH (2007) Novel approaches in microparticulate PLGA delivery systems encapsulating proteins. Journal of Materials Chemistry 17: 4002-4014.

63. Bilati U, Allémann E, Doelker E (2005) Strategic approaches for overcoming peptide and protein instability within biodegradable nano- and microparticles. Eur J Pharm Biopharm 59: 375-388.

64. Mohammadi-Samani S, Taghipour B (2014) PLGA micro and nanoparticles in delivery of peptides and proteins; problems and approaches. Pharm Dev Technol.

65. Tran VT, Karam JP, Garric X, Coudane J, Benoît JP, et al. (2012) Protein-loaded PLGA-PEG-PLGA microspheres: a tool for cell therapy. Eur J Pharm Sci 45 128-137.

66. Johnson OL, Jaworowicz W, Cleland JL, Bailey L, Charnis M, et al. (1997) The stabilization and encapsulation of human growth hormone into biodegradable microspheres. Pharm Res 14: 730-735.

67. Zhu G, Mallery SR, Schwendeman SP (2000) Stabilization of proteins encapsulated in injectable poly (lactide- co-glycolide) Nat Biotechnol 18: 52-57.

68. Zale SE, Burke PA, Bernstein H, Brickner A (1997) Composition for sustained release of non-aggregated erythropoietin.

69. Shive MS, Anderson JM (1997) Biodegradation and biocompatibility of PLA and PLGA microspheres. Adv Drug Deliv Rev 28: 5-24.

70. Semete B, Booysen L, Lemmer Y, Kalombo L, Katata L, et al. (2010) In vivo evaluation of the biodistribution and safety of PLGA nanoparticles as drug delivery systems. Nanomedicine 6: 662-671.

71. Chittasupho C, Xie SX, Baoum A, Yakovleva T, Siahaan TJ, et al. (2009) ICAM1 targeting of doxorubicin-loaded PLGA nanoparticles to lung epithelial cells. European Journal of Pharmaceutical Sciences 37: 141-150.

72. Zhang X, Sun M, Zheng A, Cao D, Bi Y, et al. (2012) Preparation and characterization of insulin-loaded bioadhesive PLGA nanoparticles for oral administration. Eur J Pharm Sci 45: 632-638.

73. Mura S, Hillaireau H, Nicolas J, Le Droumaguet B, Gueutin C, et al. (2011) Influence of surface charge on the potential toxicity of PLGA nanoparticles towards Calu-3 cells. Int J Nanomedicine 6: 2591-2605. 